\title{
Gene encoding virulence markers among Escherichia coli isolates from diarrhoeic stool samples and river sources in rural Venda communities of South Africa
}

\author{
CL Obi ${ }^{1 *}$, E Green 1 , PO Bessong 1 , B de Villiers ${ }^{2}$, AA Hoosen², EO Igumbor ${ }^{1}$ and N Potgieter ${ }^{1}$ \\ ${ }^{1}$ Department of Microbiology, University of Venda for Science and Technology, P/Bag X5050 Thohoyandou 0950, South Africa \\ ${ }^{2}$ Department of Medical Microbiology, Medical University of Southern Africa (MEDUNSA), South Africa
}

\begin{abstract}
River water sources and diarrhoeic stools of residents in the Venda Region, Limpopo Province of South Africa were analysed for the prevalence of Escherichia coli (E. coli) and the presence of virulence genes among the isolates. A control group of 100 nondiarrhoeic stool samples was included. Escherichia coli was isolated and identified by standard cultural and biochemical methods. Pathogenicity of environmental and human isolates was determined by amplification of genes associated with virulence of $E$. coli, using specific primers.

Of a total of 228 water and river sediment samples screened, E. coli was recovered from $200(87.7 \%)$, and 135 (67.5\%) of these had one or more genes associated with pathogenicity. The highest frequency of isolation of pathogenic strains was found in Ritavi River water and sediment (80.6\%), followed by Lotanyanda River (76.9\%), and the least (45.8\%) in Nzhelele River 2. Escherichia coli was recovered from all of the 252 diarrhoeic stools tested (100\%), and $119(47.28 \%)$ of these had one or more genes associated with pathogenicity. The frequency of isolation of potential pathogenic $E$. coli from humans was highly significant $(\mathrm{t}=6.3 ; \mathrm{pd} \bullet 0.01)$ in comparison to water isolates. Cytotoxic necrotizing Factor 1 ( $\mathrm{c} n f 1)$ and cytotoxic necrotising Factor 2 ( $\mathrm{cnf} 2$ ) coding for necrotoxigenic $E$. coli (NEC); bundle-forming pilus $(b f p A)$ and enteropathogenic attachment and effacement (eaeA) coding for enteropathogenic $E$. coli (EPEC), occurred in $35 \%$ and $34 \%$ respectively of river isolates. Heat-stable $(S T)$ and heat-labile $(L T)$ toxin genes coding for enterotoxigenic (ETEC) and Shiga-like toxin 1 (Stxl) and Shiga-like toxin 2 (Stx2) coding for Shiga-like toxin-producing $E$. coli (STEC) were not encountered in the river isolates. Isolates from stool samples had $21.8 \%$ and $12.6 \%$ of EPEC and NEC strains respectively; while enterotoxigenic (ETEC), Shiga-like toxin-producing (STEC) and enteroaggregative $E$. coli (EAEC) had a prevalence of 5\%,5.8\% and 5.8\% respectively. One human isolate possessed stx 2 and eae $A$ indicating $E$. coli O157: H7. No genes associated with pathogenicity were observed in human non-diarrhoeic stool isolates. Results have revealed a possibility of a recycling of pathogenic $E$. coli strains, particularly the EPEC and NEC strains, between the water sources and the local population.
\end{abstract}

Keywords: Escherichia coli, virulence markers, water, stool, Venda, South Africa

\section{Introduction}

Over $500 \times 10^{6}$ cases of acute diarrhoea have been reported to occur yearly in children aged less than 5 years across the globe (Snyder and Merson, 1982). Diarrhoeal diseases are responsible for a huge proportion of morbidity and mortality in developing countries, particularly among children (Snyder and Merson, 1982; DuPont, 1995a). Apart from protozoans such as Giardia lamblia, Entamoeba histolytica, Cryptosporidium parvum, Isospora belli, and viruses such as Rotavirus, and Norwalk-like virus, implicated in cases of diarrhoea, frequently isolated bacterial diarrhoeagenic agents include Escherichia coli, Campylobacter jejuni/coli, Salmonella, Shigella, and Aeromonas species (Obi et al., 1995, 1997; Lainson and Silva, 1999; Coker et al., 2002; Oyofo et al., 2002). Escherichia coli is, however, the focus of this study. Although a normal flora of animals and humans, some E. coli strains are pathogenic and may account for life-threatening infections. Such infections include urinary tract infections (Falagas and Gorbach, 1995), haemolytic colitis, neonatal meningitis, nosocomial septicaemia, haemolytic uremic syndrome and surgical site infections

\footnotetext{
* To whom all correspondence should be addressed.

出 +2715962 8317 / 082422 7580; fax: +2715 962 8648/4749; e-mail: obil@univen.ac.za or c355251@yahoo.com or larryobi@lantic.net Received 26 May 2003; accepted in revised form 24 October 2003.
}

(Klein et al., 1986; Thielman and Guerrant, 1999). Diarrhoeal diseases due to the virulent strains have been extensively reported and account for a substantial degree of morbidity and mortality in different age groups (El-Sheikh and El-Assouli, 2001; Galane and Le Roux, 2001). Virulent strains of E. coli include enteropathogenic E. coli (EPEC), enteroinvasive E. coli (EIEC), enterohaemorrhagic E. coli (EHEC), enteroaggregative E. coli (EAEC), and enterotoxigenic E. coli (ETEC) (Giron et al., 1991; Falbo et al., 1992; Blanco et al., 1992; Chan et al., 1994; Levine, 1987). The clinico-epidemiological patterns of the virulent strains vary, and association with travellers' diarrhoea, extra-intestinal infections, acute, chronic or persistent diarrhoea are known (Falbo et al., 1992; Chan et al., 1994). Indices of pathogenicity among E. coli strains include pili, k-antigen, haemolysin, adhesive factor, enterotoxins, cytotoxins, effacement factors and cytotoxic necrotic factors (Galane and Le Roux, 2001).

Animals, humans and the environment including water sources serve as natural habitats of virulent strains of E. coli (DuPont, 1995; Nataro et al., 1998; Griffin, 1999; Kuhnert et al., 2000; Stephan and Schumacher, 2001). Infection with pathogenic E. coli strains is closely linked to poor sanitation and personal hygiene. In developing countries infection could be due to the consumption of contaminated water from wells, rivers, and other surface waters (Grasso et al., 2000; Welch et al., 2000; Tumwine et al., 2002). In many rural areas of South Africa, clean potable water and sanitation are 


\begin{tabular}{|c|c|c|c|c|c|c|c|c|c|c|}
\hline 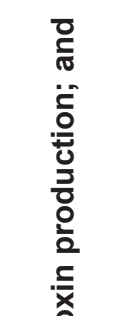 & 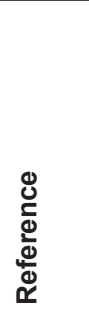 & 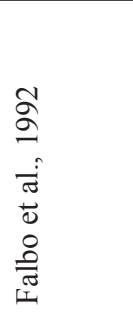 & 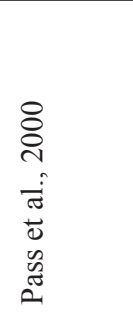 & 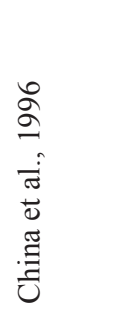 & 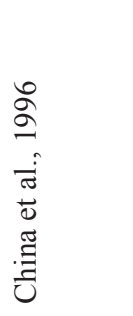 & 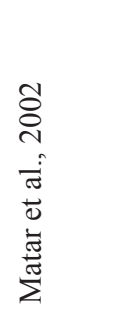 & 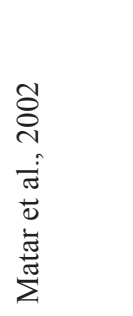 & 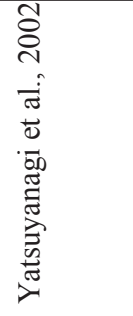 & 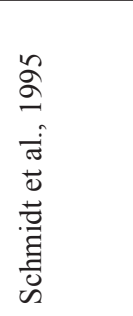 & 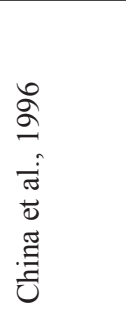 \\
\hline 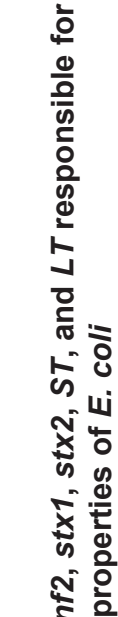 & 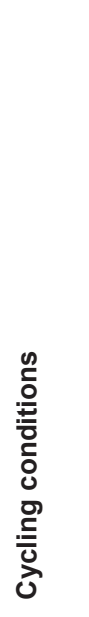 & 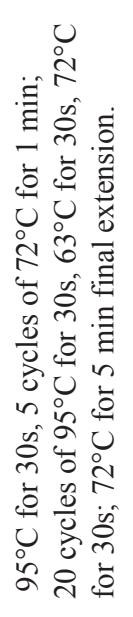 & 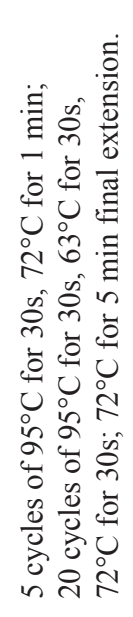 & 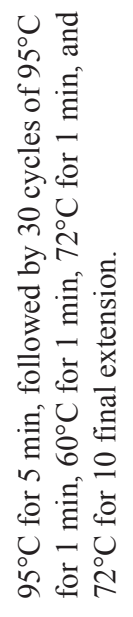 & 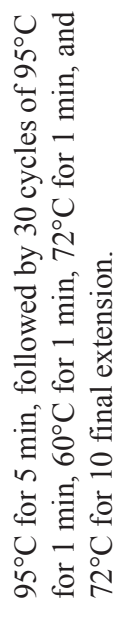 & 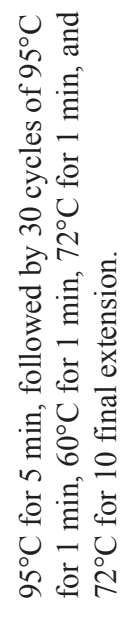 & 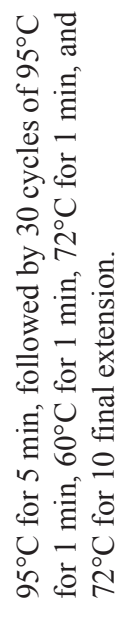 & 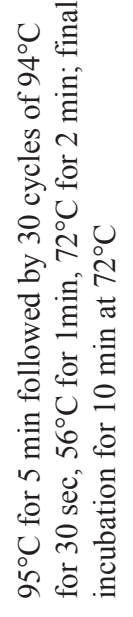 & 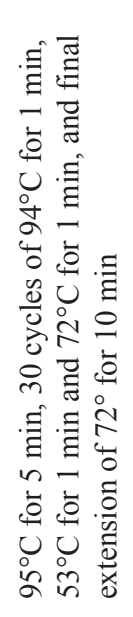 & 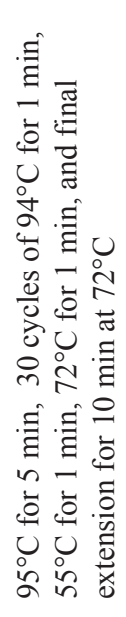 \\
\hline 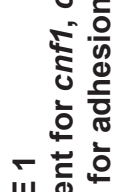 & 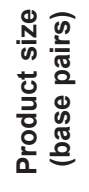 & $\begin{array}{l}\stackrel{8}{0} \\
\stackrel{\infty}{\sim}\end{array}$ & $\begin{array}{l}\text { हे } \\
\text { के }\end{array}$ & $\begin{array}{l}\text { 今े } \\
\stackrel{1}{0}\end{array}$ & 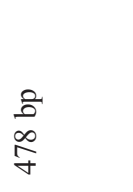 & 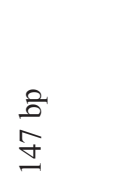 & $\begin{array}{l}\text { डे } \\
\text { ले }\end{array}$ & $\begin{array}{l}\text { हे } \\
\text { ڤें } \\
\text { ले }\end{array}$ & $\begin{array}{l}\text { 今े } \\
0 \\
0 \\
0\end{array}$ & $\begin{array}{l}\text { aे } \\
\text { aे } \\
\text { in }\end{array}$ \\
\hline 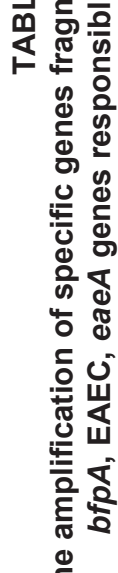 & 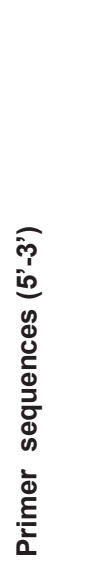 & 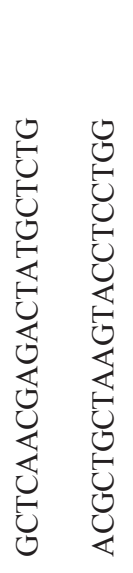 & 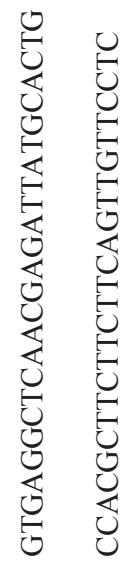 & 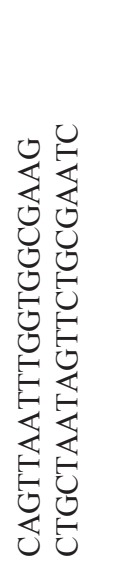 & 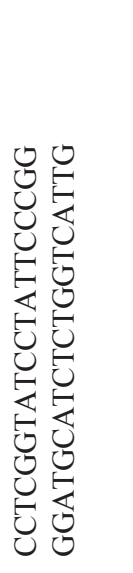 & 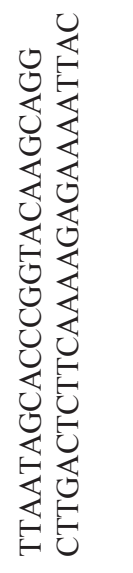 & 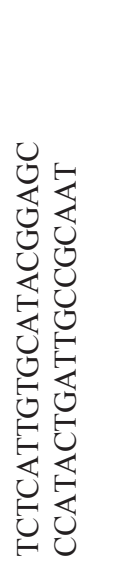 & 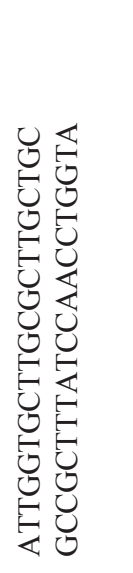 & 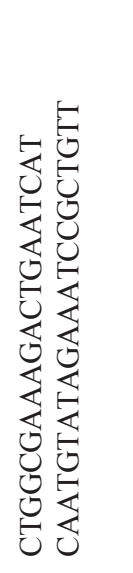 & 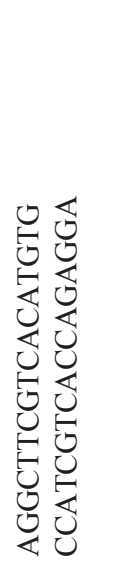 \\
\hline 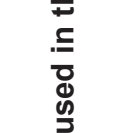 & 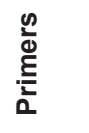 & 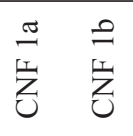 & 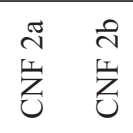 & 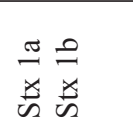 & $\begin{array}{l}\stackrel{N}{N} \stackrel{\sim}{\sim} \\
\ddot{n} \\
\omega\end{array}$ & 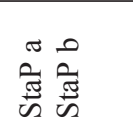 & 点 & 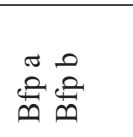 & 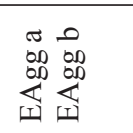 & $\begin{array}{l}\tilde{\sigma} 0 \\
\tilde{\Xi} \\
\tilde{\Psi} \\
\tilde{I}\end{array}$ \\
\hline 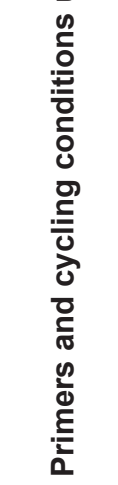 & 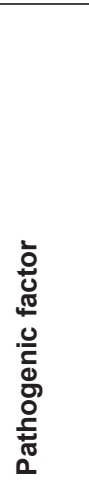 & 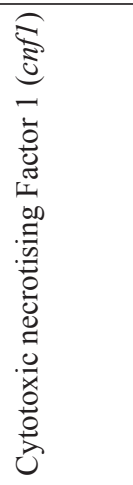 & 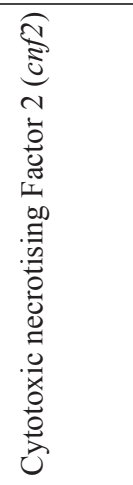 & 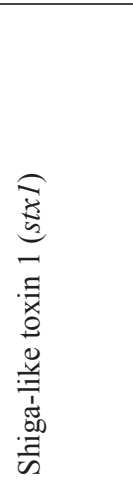 & 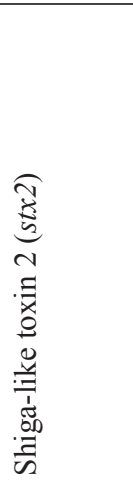 & 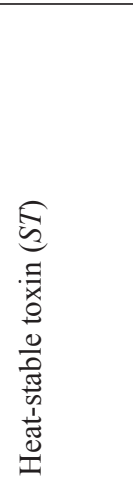 & 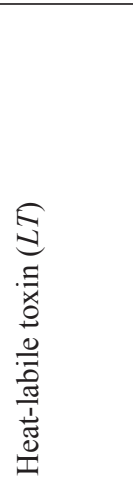 & 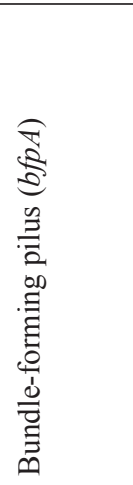 & 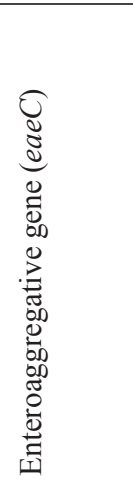 & 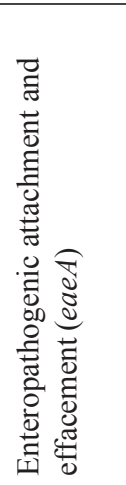 \\
\hline
\end{tabular}


lacking. Village communities depend on untreated water from rivers, wells, fountains and other surface waters for drinking, laundry, and recreational purposes. (Von Shirnding et al., 1993; Pegram et al., 1998). A previous report on the microbial quality of river water sources in Venda rural communities in Limpopo, South Africa, showed that the water sources were unsafe for human consumption, and E. coli was the predominant potential pathogen isolated. (Obi et al., 2002). Values reported for faecal coliforms, total coliforms, heterotrophic plate counts, enterococci and somatic coliphages (Obi et al., 2002) exceeded minimum acceptable values prescribed in the guidelines of the Department of Water Affairs and Forestry (DWAF, 1996).

In this study, stool samples and river water sources in the Venda Region, Limpopo Province of South Africa were screened for the prevalence of $E$. coli and the presence of virulence factors associated with the organism using the polymerase chain reaction in an endeavour to elucidate the molecular epidemiology of virulent strains.

\section{Materials and methods}

\section{Sources of samples and study sites}

Five hundred millilitres of river water and $500 \mathrm{~g}$ of river sediments were collected from six rivers in the Venda region of South Africa. The rivers were: Nzhelele 1, Nzhelele 2, Elim, Ritavi, Lotanyanda and Xikari. A total of 228 river samples were collected, and 252 diarrhoeic stool samples were obtained on a weekly basis from outpatients attending the Elim and Siloam Hospitals in the same region. One hundred non-diarrhoeic stools were included as controls. Stool samples were collected from individuals who make use of one or more of the rivers as their water sources. Water and stool samples were collected between June 2001 and September 2002, and processing was done within $6 \mathrm{~h}$. Informed consent was obtained before the collection of stool samples. Diarrhoea in this study was defined as the passage of watery stools at least thrice daily.

\section{Isolation and identification of E. coli}

Isolation of $E$. coli from stool samples was done as previously described (Maier et al., 2000). Briefly, stool samples were inoculated unto nutrient broth (Merck, South Africa), and incubated at $37^{\circ} \mathrm{C}$ for $24 \mathrm{~h}$, followed by streaking on eosin methylene blue agar (Merck, South Africa), and incubated again at $37^{\circ} \mathrm{C}$ for $24 \mathrm{~h}$. Five millilitres river water and $10 \mathrm{~g}$ river sediment were used as inocula for the isolation of $E$. coli from river water and river sediments. Dark blue colonies or colonies showing metallic sheen were confirmed using biochemical tests as described (Edward and Ewing, 1972; Forbes et al., 1998).

\section{Amplification of pathogenic gene sequences}

Bacterial DNA was isolated as described by Reischl et al. (2002). Briefly, an overnight bacterial culture was suspended in sterile distilled water and heated at $94^{\circ} \mathrm{C}$ for $13 \mathrm{~min}$; this was followed by centrifugation at $14000 \mathrm{r} \cdot \mathrm{min}^{-1}$ for $15 \mathrm{~min}$ to pellet the cell debris. The supernatant was used as template for amplification reactions. Gene regions coding for the following pathogenic properties were amplified for each bacterial isolate: Bundle-forming pilus $(b f p A)$, cytotoxic necrotising Factors 1 and $2(c n f 1, c n f 2)$, heat-labile toxin $(L T)$, heat-stable toxin $(S T)$, Shiga-like Toxin 1 and 2 (stx1, stx2), enteropathogenic attachment and effacement (eaeA), and enteroaggregative (EAEC) gene, using specific primers. For each gene of interest the master mix consisted of $50 \mathrm{mM} \mathrm{KCl,} 1 \mathrm{mM}$ Tris $\mathrm{HCl}, 1.5 \mathrm{mM} \mathrm{MgCl}, 100 \mathrm{mM}$ of dNTPs and $1 \mathrm{U}$ of Taq polymerase. Five microlitres of DNA template was added to $45 \mathrm{m \ell}$ of the master mix and amplified accordingly. Specific primers and amplification conditions for the different pathogenic gene coding regions were employed as previously described (Falbo et al., 1992; Schmidt et al., 1995; Pass et al., 2000; China et al., 1996; Matar et al., 2002; Yatsuyanagi et al., 2002;). Details are shown in Table 1. Amplified gene products were verified by gel electrophoresis ( $2 \%$ agarose) at $80 \mathrm{~V}$ for $90 \mathrm{~min}$ and visualised under ultraviolet light. Isolates were classified according to the genes detected as follows: $c n f 1$ and $c n f 2$ for necrotoxigenic; $S T$ and $L T$ for enterotoxigenic; st 1 and st $x 2$ for Shiga toxin producing; $b f p A$ and $e a e A$ for enteropathogenic, and EAEC for enteroaggregative $E$. coli. Reference strains representing the amplified genes, BM2-1 (cnf1), B20A (cnf2), C600-933J (stx1), C600-933W (stx2), and previously obtained amplicons of $S T, L T, b f p A$, eaeA and EAEC were obtained from the Department of Medical Microbiology, Medical University of Southern Africa, South Africa.

\section{Results}

\section{Frequency of isolation of pathogenic $E$. coli from water sources}

Of a total of 228 river water and river sediment samples collected, E. coli was recovered from $200(87.7 \%)$, and 135 (67.5\%) of these had one or more of the genes responsible for pathogenicity of $E$. coli. The highest frequency of isolation of pathogenic strains was found in Ritavi River surface and sediment $(80.6 \%)$, followed by Lotanyanda River (76.9\%), and the least number of isolates was found in Nzhelele River 2 (45.8\%)(Table 2).

\begin{tabular}{|c|c|c|}
\hline \multicolumn{3}{|c|}{$\begin{array}{l}\text { TABLE } 2 \\
\text { Frequency of isolation of } E \text {. coli and pathogenic } \\
\text { E. coli strains from six rivers and their sediments, } \\
\text { and from diarroeal stools from in-patients of two } \\
\text { hospitals, in the Limpopo Province of South Africa }\end{array}$} \\
\hline $\begin{array}{l}\text { Sampling sites } \\
\text { ( } \mathrm{n}=\text { number of samples) }\end{array}$ & $\begin{array}{l}\text { Number of (\%) } \\
\text { E. coli isolates }\end{array}$ & $\begin{array}{l}\text { Number of } \\
\text { pathogenic } \\
\text { E. coli } \\
\text { isolates (\%) }\end{array}$ \\
\hline \multicolumn{3}{|c|}{ Rivers $(n=$ Surface water + sediments) } \\
\hline $\begin{array}{ll}\text { Nzhelele 1 } & (\mathrm{n}=29) \\
\text { Nzhelele 2 } & (\mathrm{n}=26) \\
\text { Elim bridge } & (\mathrm{n}=31) \\
\text { Ritavi } & (\mathrm{n}=34) \\
\text { Xikari } & (\mathrm{n}=78) \\
\text { Lotanyanda } & (\mathrm{n}=30) \\
\text { Total } & (\mathbf{n}=\mathbf{2 2 8})\end{array}$ & $\begin{array}{l}24(82.7 \%) \\
24(92.3 \%) \\
26(83.9 \%) \\
31(91.1 \%) \\
69(88.4 \%) \\
26(86.7 \%) \\
200(\mathbf{8 7 . 7 \% )}\end{array}$ & $\begin{array}{l}16(66.7 \%) \\
11(45.8 \%) \\
14(53.8 \%) \\
25(80.6 \%) \\
49(71.0 \%) \\
20(76.9 \%) \\
135(67.5 \%)\end{array}$ \\
\hline \multicolumn{3}{|l|}{ Hospitals (diarrhoeic stools) } \\
\hline $\begin{array}{l}\text { Siloam Hospital }(\mathrm{n}=124) \\
\text { Elim Hospital } \quad(\mathrm{n}=128) \\
\text { Total } \\
\text { Controls (non-diarrhoeic } \\
\text { stools, } \mathbf{n}=\mathbf{1 0 0})\end{array}$ & $\begin{array}{l}124(100 \%) \\
128(100 \%) \\
252(\mathbf{1 0 0 \% )} \\
\mathbf{1 0 0}(\mathbf{1 0 0 \% )}\end{array}$ & $\begin{array}{l}58(46.8 \%) \\
61(47.7 \%) \\
\mathbf{1 1 9}(\mathbf{4 7 . 2 \% )}) \\
\mathbf{0 0}(\mathbf{0 . 0 \%})\end{array}$ \\
\hline
\end{tabular}




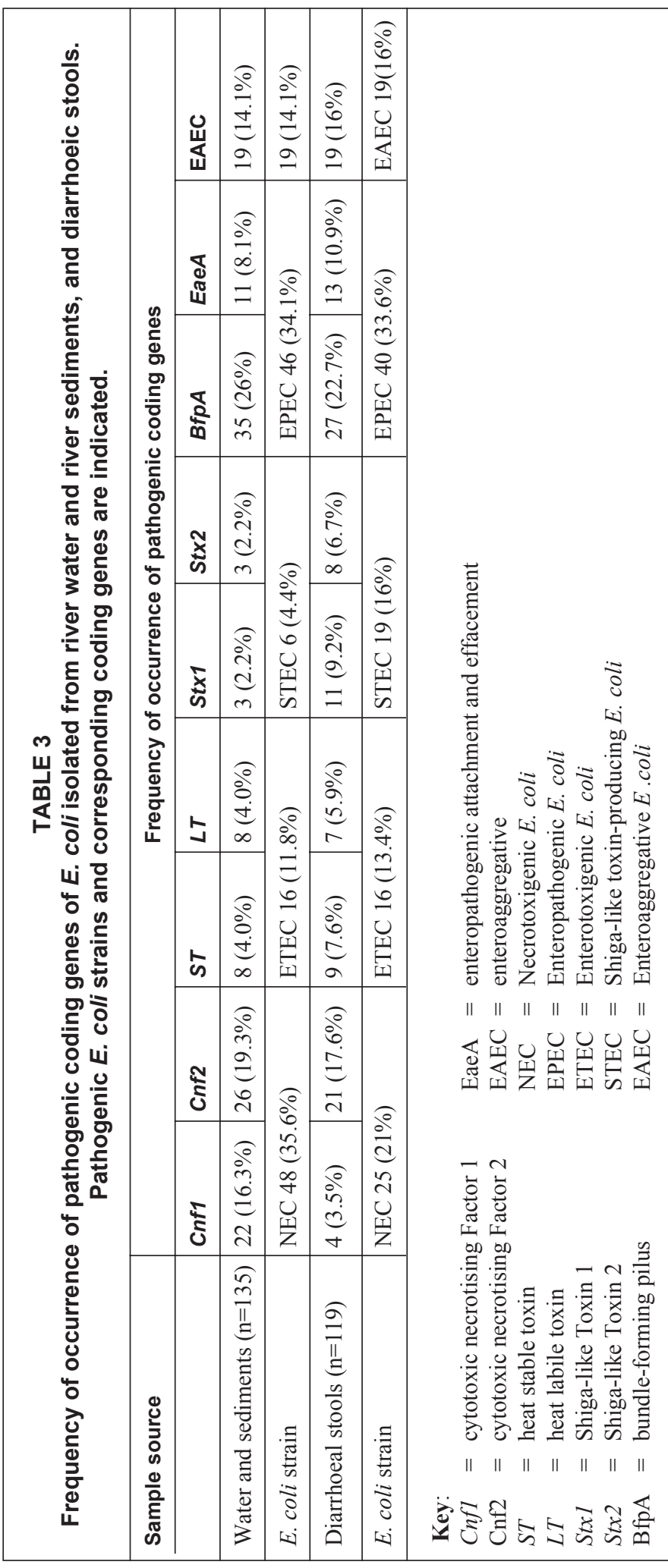

\section{Frequency of isolation of pathogenic $E$. coli from humans}

E. coli was recovered from all of the $252(100 \%)$ diarrhoeic stool specimens screened. However, $119(47.28 \%)$ of these had genes associated with pathogenicity. Among the 124 isolates obtained from Siloam Hospital, 58 (46.8\%) were pathogenic, while 61 (47.7\%) were pathogenic strains among the 128 isolates obtained from Elim Hospital. E. coli was isolated from all the control non-diarrhoeic stools samples $(100 \%)$. However, no pathogenic strains were identified (Table 2). The frequency of isolation of potential pathogenic $E$. coli from humans was highly significant $(\mathrm{t}=6.3$; $\mathrm{pd} \bullet 0.01)$ in comparison to river water sources.

\section{Frequency of occurrence of pathogenic coding genes of $E$. coli isolates}

The $b f p A$ gene coding for enteropathogenic $E$. coli (EPEC) was most frequently detected (26\%) among $E$. coli isolates from river water sources and their sediments; followed by cnf2 $(19.3 \%)$, and $c n f 1(16.3 \%)$, both coding for necrotoxigenic E. coli (NEC). ST, LT, and stx1,stx2, and EAEC coding for enterotoxigenic E. coli (ETEC), Shigalike toxin-producing strains (STEC), and enteroaggregative E. coli (EAEC) occurred with a frequency of $4 \%, 4 \%, 2 \%$, $2 \%$ and $14.1 \%$ respectively. Overall genes coding for NEC were most frequent $(35.5 \%)$, followed by genes coding for EPEC (34.1\%). Among human E. coli isolates BfpA occurred most frequently $(22.7 \%)$, followed by cnf2 $(17.6 \%)$, and the least was cnfl (3.5\%). Genes coding for EPEC were most observed (33.6\%), followed by genes coding for NEC $(21 \%)$ (Table 3). One human isolate contained the stx 2 and eae $A$ genes. No other isolate had more than one gene coding for pathogencity. No genes associated with pathogenicity were identified in the isolates obtained from non-diarrhoeal stools. A representative gel electrophoresis profile of amplified products of the investigated pathogenic coding genes is shown in Fig. 1.

\section{Discussion}

In the absence of treated potable water, many rural communities in South Africa depend on rivers and other water bodies for domestic and recreational purposes. Unfortunately, these water sources are not protected, and are open to microbial contamination from humans, animals and the environment (Nevondo and Cloete, 1999; Lehloesa and Muyima, 2000). River water sources in the Limpopo Province have been shown to be heavily contaminated with $E$. coli (Obi et al., 2002). Moreover, strains of $E$. coli have been implicated in a variety of clinical infections. The presence of pathogenic $E$. coli in water sources is always of public health concern.

In this study, rivers used for drinking and washing purposes in the Venda Region of the Limpopo Province were found to be contaminated with pathogenic strains of $E$. coli. The detection of necrotoxigenic and enteropathogenic strains means that these water sources present a health hazard to their users. Among the water isolates NEC (35.6\%) and EPEC (34.1\%) were most frequently encountered. EPEC has been shown to be a major cause of diarrhoea in young children (Kuhnert et al., 2000), while NEC is responsible for diarrhoea in cattle (Orden et al., 1999; DebRoy et al., 2001). NEC isolated from animals and humans can belong to the same serogroups and produce or carry genes coding for fimbrial and afimbrial adhesins (Mainil et al., 1999). The isolation of NEC from some of the rivers investigated may confirm the faecal contamination of these water sources by grazing cattle, and raises the question of possible zoonotic infections. We observed $21 \%$ NEC isolates from diarrhoeal stools, and none from the control 


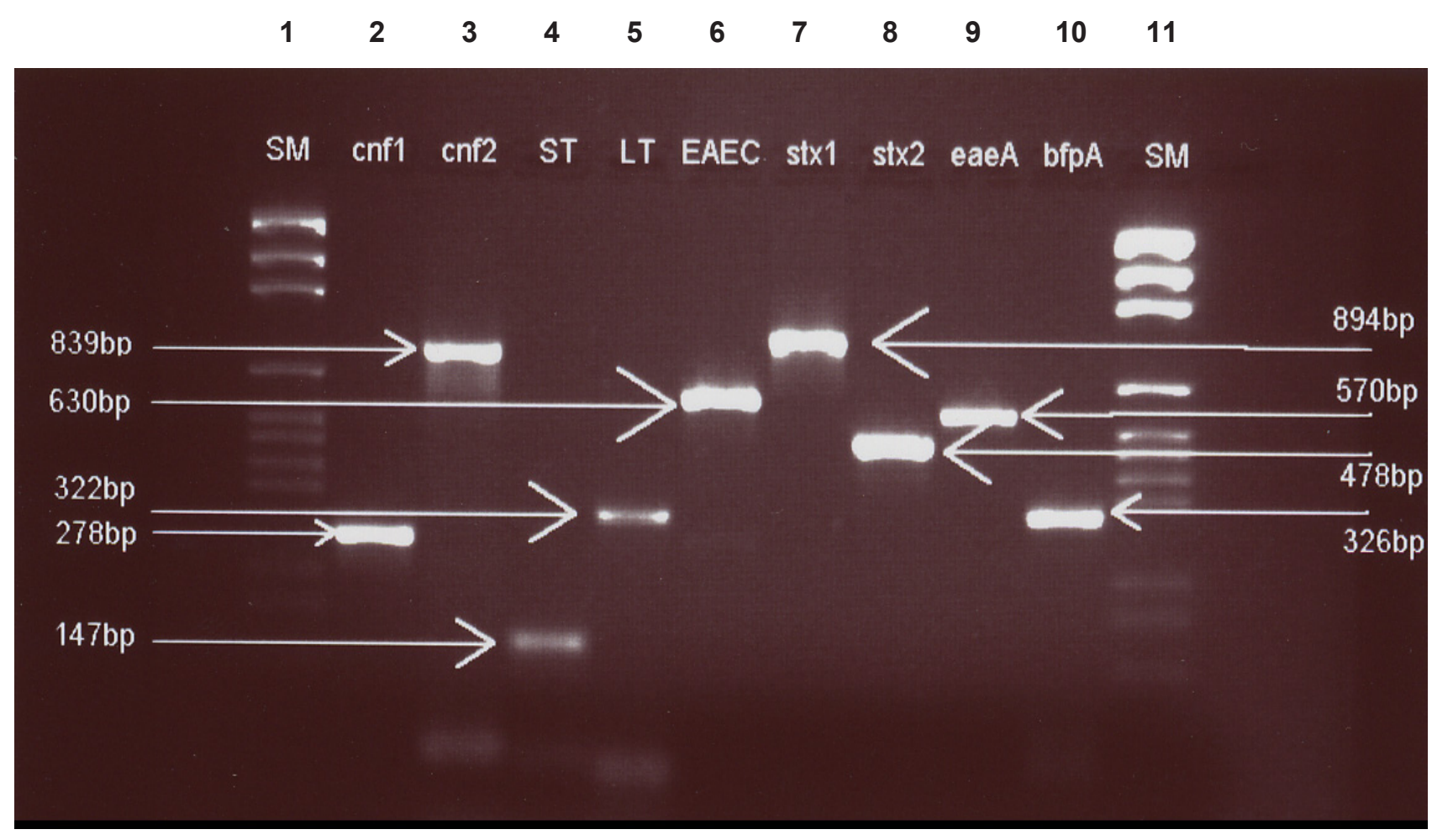

Figure 1

A representative gel electrophoresis profile of different virulence genes of isolated E. coli. Lanes 1 and 11, molecular weight marker (GIBCO BRL 1000kb ladder); Lane 2, cnf1; Lane 3, cnf2; Lane 4, ST; Lane 5, LT; Lane 6, EAEC;

Lane 7, Stx1; Lane 8, Stx2; Lane 9, eaeA; Lane 10, bfpA.

group. The prevalence of EPEC observed in this study among diarrhoeagenic human isolates was marginally higher (33.6\%) compared to the report of Galane and Le Roux (2001), who reported a prevalence rate of $26.5 \%$ among South African children with diarrhoea. In this study, a marginally higher proportion of atypical EPEC (32.5\%) against $28.2 \%$ reported by Galane and Le Roux (2001) was noted. In our findings, NEC (21\%), EPEC $(33.6 \%)$ were also the predominant isolates from clinical (stool) samples. ETEC (13.4\%), STEC (16\%) and EAEC (16\%) occurred more frequently in stool isolates than in water isolates. One human isolate had stx2 and eaeA genes indicating a pathogenicity island typical of $E$. coli $\mathrm{O} 157: \mathrm{H} 7$, known to cause diarrhoea in infants, haemorrhagic colitis, and haemolytic uremic syndrome, a severe clinical manifestation of infections with Shiga-like toxin-producing E. coli (Blank et al., 2003; Tozzi et al., 2003). The predominance of NEC and EPEC in both the human and water isolates indicates a possibility of a recycling of pathogenic $E$. coli strains between the water sources and the local population. This could explain an endemic situation of diarrhoeal cases due to E. coli. EPEC and ETEC have been identified as leading pathogens in developing countries, particularly in children (Georges et al., 1984). Finally, this study has revealed the presence of virulence markers in E. coli isolates from river water sources and stool samples of patients with diarrhoea and also emphasises the importance of safe water supply, good hygiene and sanitation practices in rural communities.

\section{Acknowledgements}

This study was supported by the National Research Foundation (NRF) and the Water Research Commission (WRC), South Africa, through research grants awarded to Prof CL Obi, University of Venda, Thohoyandou, South Africa.

\section{References}

BLANK TE, LACHER DW, SCALETSKY ICA, ZHONG H, WHITTAM TS and DONNENBERG MS (2003) Enteropathogenic Escherichia coli O157 strains from Brazil. Emerg. Inf. Dis. 9 (1) 113-115.

BLANCO J, GONZALEZEA, ESPINOSA P, BLANCO M, GARABAL JI and ALANSO MP (1992) Enterotoxigenic and necrotizing Escherichia coli in human diarrhoea in Spain. Eur. J. Epidemiol 8 548-552.

CHAN KN, PHILLIPS AD, KNUTTON S, SMITH HR and WALKER SMITH JA (1994) Enteroaggregative Escherichia coli: Another cause of acute and chronic diarrhoea in England. J. Pediatr. Gastroenterol. Nutr. 18 87-91.

CHINA B, PIRSON V and MAINIL J (1996) Prevalence and molecular typing of attaching and effacing Escherichia coli among calf population in Belgium. J. Vet. Microbiol. 63 256-259.

COKER AO, ISOKPEHI RD, BOLAJI NT, AMISU OA and OBI CL (2002) Human campylobacteriosis in developing countries. Emerg. Inf. Dis. 8 (3) 237-243.

DEBROY C and MADDOX CW (2001) Identification of virulence attributes of gastrointestinal Escherichia coli isolates of veterinary significance. Anim. Health Res. Rev. 2 (2) 129-140.

DEPARTMENT OF WATER AFFAIRS AND FORESTRY (DWAF) (1996) South African Water Quality Guideline for Domestic Use ( $2^{\text {nd }}$ edn.), Pretoria.

DUPONT HL (1995) Diarrhoeal diseases in the developing world. Infect. Dis. Clin. North Am. 9 313-324.

EDWARD PR and EWING WH (1972) Identification of Enterobacteriaceae $\left(3^{\text {rd }}\right.$ edn.) International Student Publication. Burgess, Minneapolis, USA. 26-28. 
EL-SHEIKH SM and EL-ASSOULI SM (2001) Prevalence of viral, bacterial and parastic enteropathogens among young children with acute diarrhoea in Jeddah, Saudi Arabia. J. Health. Popul. Nutr. 19 (1) 25-30.

FALAGAS M and GORBACH S (1995) Practice guidelines: Urinary tract infections. Infect. Dis. Clin. Pract. 4 241-257.

FALBO V, FAMIGLIETTI M and CAPRIOLI A (1992) Gene block encoding production of cytotoxic necrotising factor 1 and hemolysin in Escherichia coli. J. Infect. Immun. 7 873-880.

FORBES BA, SAHM DF and WEISSFELD AS (1998) Diagnostic Microbiology (10 $0^{\text {th }}$ edn.). Mosby Inc. 384-388.

GALANE PM and LE ROUX M (2001) Molecular epidemiology of Escherichia coli isolated from young South African children with diarroeal diseases. J. Health. Popul. Nutr. 19 (1) 31-37.

GEORGES MC, WACHSMUTH IK, MEUNIER DM, NEBOUT N, DIDIER F, SIOPATHIS MR, GEORGES AJ (1984) Parasitic, bacterial, and viral enteric pathogens associated with diarrhoea in the Central African Republic. J. Clin. Microbiol. 19 (5) 571-575.

GIRON JA, ASU HO and SHOONIK GK (1991) An inducible bundleforming pilus of enteropathogenic Escherichia coli. Sci. 254 710-713.

GRASSO GM, SAMMARCO ML, RIPABELLI G and FANELLI I (2000) Enumeration of Escherichia coli and coliforms in surface water by multiple tube fermentation and membrane filter methods. Microbios 103 (405) 119-125.

GRIFFIN PM (1999) Escherichia coli O157:H7 and other enterohemorrhagic Escherichia coli. In: Blaser MJ, Smith PD, Ravdin JI, Greenberg HB and Guerrant RL (eds.) Infections of the Gastrointestinal Tract. Raven Press, New York. 739-761.

KLEIN JO, FEIGIN RD and McCRACKEN Jr GH (1986) Report of the task force on diagnosis and management of meningitis. Pediatrics $\mathbf{7 8}$ 959-982.

KUHNERT P, BOERLIN P and FREY J (2000) Target genes of virulence assessment of Escherichia coli isolates from water, food and the environment. Fed. Eur. Microbiol. Soc. Rev. 24 107-117.

LAINSON R and DA SILVA BAM (1999) Intestinal parasites of some diarrhoeic HIV-positive individuals in North Brazil, with particular reference to Isospora belli Wenyon, 1923 and Dientamoeba fragilis Jepps \& Dobell, 1918. Mem. Inst. Oswaldo Cruz 94 (5) 611-613.

LEHLOESA LJ and MUYIMA NYO (2000) Evaluation of impact of household treatment procedures on the quality of groundwater supplies in the rural community of the Victoria District, Eastern Cape. Water SA 26 (2) 285-290.

LEVINEMM(1987)Escherichia coli that cause diarrhoea: Enterotoxigenic, enteropathogenic, enteroinvasive, enterohaemorrhagic and enteroadherent. J. Infect. Dis. 164 331-337.

MAIER RM, PEPPER IL and GERBA CP (2000). Nucleic acid-based methods of analysis. In: Marlowe EM, Josephson KL and Pepper IL (eds.) Environmental Microbiology. Academic Press, California. 287-315.

MAINIL JG, JACQUEMIN E, POHL P, FAIRBROTHER JM, ANSUINI A, LE BOUGUENEC C, BALL HJ, DE RYCKE J and OSWALD E (1999) Comparison of necrotoxigenic Escherichia coli isolates from farm animals and from humans. Vet. Microbiol. 70 (1-2) 123-135.

MATAR GM, ADBO D, KHNEISSER I, YOUSSEF M, ZOUHEIRY H, ADBELNOUR G and HARAKEH HS (2002). The multiplex-PCR based detection and genotyping of diarrhoeagenic Escherichia coli in diarrhoea stools. Ann. Trop. Med. Parasitol. 96 (3) 317-324.

NATARO JP and KAPER JB (1998) Diarrhoeagenic Escherichia coli. Clin. Microbiol. Rev. 11 142-201.

NEVONDO TS and CLOETE TE (1999). Bacterial and chemical quality of water supply in Dertig Village Settement. Water SA 25 (2) 215-220

OBI CL, COKER AO, EPOKE J and NDIP RN (1995) Aeromonas and Plesiomonas species as bacterial agents of diarrhoea in urban and rural areas of Nigeria: Antibiograms of isolates. Cent. Afr. J. Med. 4 (12) $397-403$
OBI CL, COKER AO, EPOKE J and NDIP RN (1997) Enteric bacterial pathogens in stools of residents of urban and rural regions in Nigeria: A comparison of patients with diarrhoea and controls without diarrhoea. J. Diarrhoeal. Dis Res. 15 (4) 241-247.

OBI CL, POTGIETER N, BESSONG PO and MATSAUNG G (2002) Assessment of the microbial quality of river water sources in rural communities in South Africa. Water SA 28 (3) 287-292.

ORDEN JA, RUIZ-SANTA-QUITERIA JA, CID D, GARCIA S and DE LAFUENTER (1999) Prevalence and characteristics of necrotoxigenic Escherichia coli (NTEC) strains isolated from diarrhoeic dairy calves. Vet. Microbiol. 66 (4) 265-273.

OYOFO BA, SUBEKTID, TJANIADIP, MACHPUD K, KOMALARINI S, SETIAWAN B, SIMANJUNTAK C, PUNJABI N, CORWIN AL, WASFY M, CAMPBELL JR and LESMANA M (2002) Enteropathogens associated with acute diarroea in community and hospital patients in Jakarta, Indonesia. FEMS Immunol. Med. Microbiol 34 (2) 139-146.

PASS MA, ODERA R and BATT RM (2000) Multiplex PCRs for identification of Escherichia coli by using multiplex PCR assays for stx1, stx2 eaeA, enterohemorrhagic $E$. coli hlyA, rfb0111, and rfb0157. J. Clin. Microbiol. 36 598-602.

PEGRAM GC, ROLLINS N and ESPAY Q (1998) Estimating the cost of diarrhoea and epidemic dysentery in KwaZulu-Natal and South Africa. Water SA 21 (1) 11-20.

REISCHL U, YOUSSEF MT, KILWINSKI J, LEHN N, ZHANG WL, KARCH H and STROBINE NA (2002) Real time fluorescence PCR assays for the detection and characterization of Shiga toxin, Intimin, and enterohemolysin genes from Shiga toxin-producing E. coli. J. Clin. Microbiol. 40 (7) 2555-2565.

SCHIMDT H, KNOP C, FRANKE S, ALEKSIC S, HEESEMANN J and KARCH H (1995) Development of PCR for screening of enteroaggregative Escherichia coli. J. Clin Microbiol. 33 701-705.

SNYDER JD and MERSON MH (1982) The magnitude of the global problem of acute diarrhoea disease: A review of active surveillance data. Bull. World Health Org. 60 603-613.

STEPHAN R and SCHUMACHER S (2001) Resistance patterns of nonO157 Shiga toxin-producing Escherichia coli (STEC) strains isolated from animals, food and asymptomatic human carriers in Switzerland. Lett. Appl. Microbiol. 32 (2) 114-117.

THIELMAN NM and GUERRANT RL (1999) Escherichia coli. In: Yu VL, Merigan (Jr) TC and Barriere SL (eds). Epidemiology and Pathogenesis of Escherichia Coli. The Williams \& Wilkins Company, Baltimore. 88-200.

TOZZI AE, CAPRIOLI A, MINELLI F, GIANVITI A, DE PETRIS L, EDEFONTI A, MONTINI G, FERRETTI A, DE PAULO T, GAIDO $\mathrm{M}$ and RIZZONI G (2003) Shiga toxin-producing Escherichia coli infections associated with hemolytic uremic syndrome, Italy, 19882000. Emerg Inf. Dis. 9 (1) 106-108.

TUMWINE JK, THOMPSON J, KATUA-KATUA M, MUJWAJUZI M, JOHNSTONE N and PORRAS L (2002) Diarrhoea and effects of different water sources, sanitation and hygiene behaviour in East Africa. Trop. Med. Int. Health 7 (9) 750-756.

VON SCHIRNDING Y, YEAH D, and MATHEE A (1993) Health aspects of sanitation, with special references to South Africa. J. Comprehensive Health 4 (3/4) 73-79.

WELCH P, DAVID J, CLARKE W, TRINIDADE A, PENNER D, BERNSTEIN S, MCDOUGALL L and ADESIYUN AA (2000) Microbial quality of water in rural communities in Trinidad. Rev. Panam. Salud. Publica 8 (3) 172-80

YATSUYANAGI J, SAITO S, SATO H, MIYAGIMA Y, AMANO KI and ENOMOTOK(2002) Characterization of enteropathogenic and enteroaggregative Escherichia coli isolated from diarrhoeal outbreaks. J. Clin. Microbiol. 40 (1) 294-297. 